\title{
UNCLASSIFIED
}

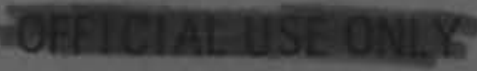

\section{FAST FLUX TEST FACILITY CRITERIA}

FOR CONTAINMENT

N. G. Wittenbrock

December 1967

\section{AEC RESEARCH \& DEVELOPMENT REPORT}

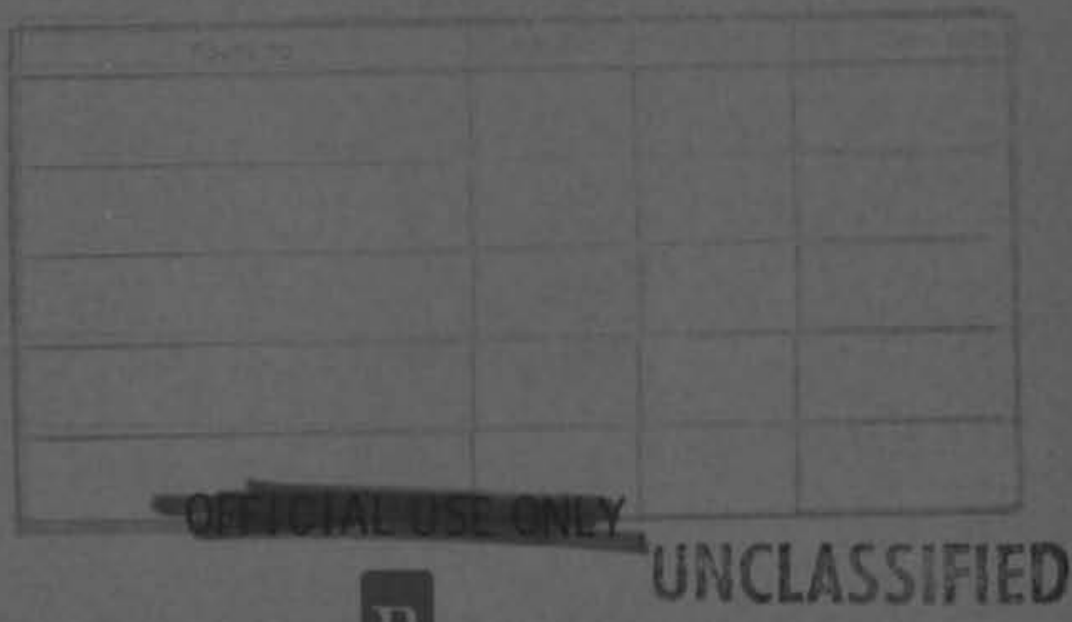




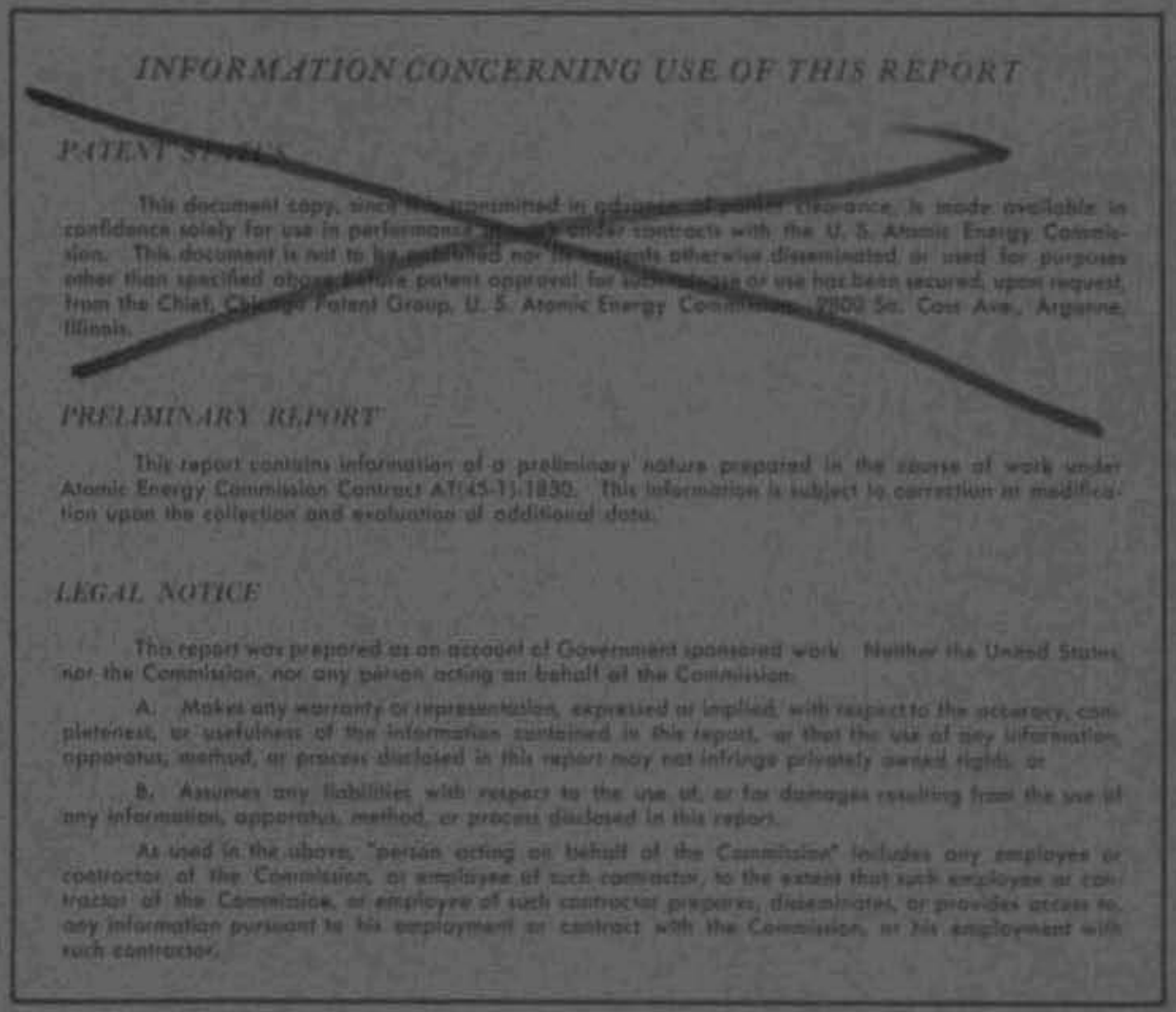

\author{
PACIFIC NORTHWEST LABORATORY \\ Ricriano. WhStimator \\ operated by \\ BATTELIE MEMORIAL INSTMUTE \\ for the \\ UNITED STATES ATOMIC ENERGY COMMISSION UNDER CONTRACT AT(45-1)-1830
}

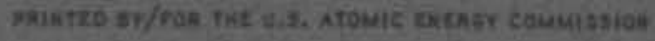


UACMASBEDD

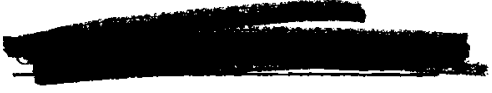

BNWL -607

33679000607178

\section{FAST FLUX TEST FACILITY CRITERIA FOR CONTAINMENT}

By

N. G. Wittenbrock

December 1967

Approved by

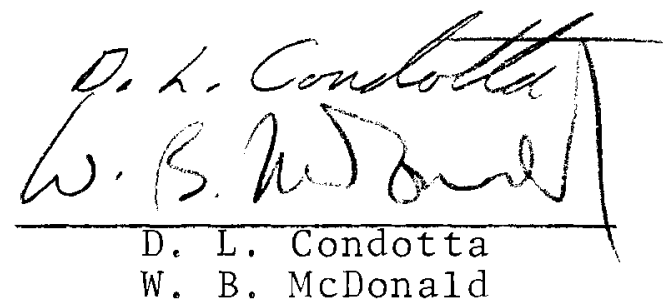

PACIFIC - NORTHWEST LABORATORY

RICHLAND, WASHINGTON

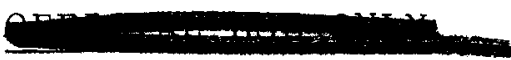

UNCLASSIFIED 


\section{TABLE OF CONTENTS}

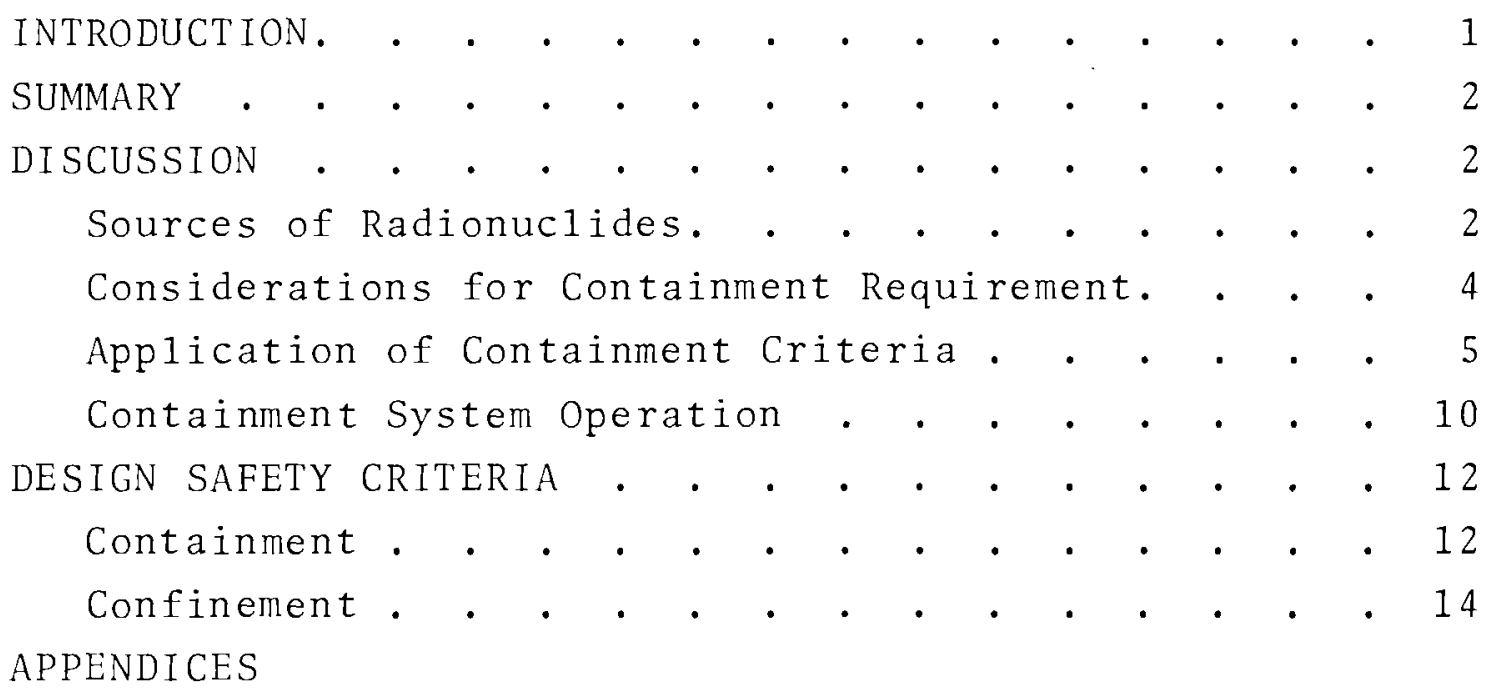

A. Estimated Fission Product Decay Heat . . . . A-1

B. FFTF Fuel Storage Basin Criticality Accidents . B-1

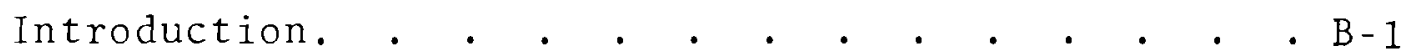

Fuel Design and Criticality Configurations. . . . B-1

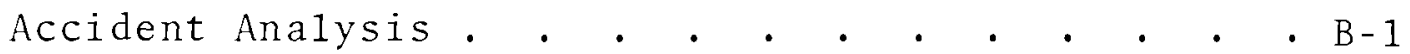

Slow Reactivity Addition Accidents . . . . . . . B-2

Fast Reactivity Addition Accidents . . . . . . B-4

Summary • • • • • • . • • • • • • • • B-5

Further Work. • . . . . . . . . . . . . B-6 DISTRIBUTION • • • • • • • • • • • • • • • • C-1 


\title{
FAST FLUX TEST FACILITY CRITERIA FOR CONTAINMENT
}

\author{
N. G. Wittenbrock
}

\section{INTRODUCTION}

A statement of the Pacific Northwest Laboratory (PNL) philosophy of reactor containment for the Fast Flux Test Facility (FFTF) is needed. These criteria were prepared to explain the PNL philosophy and to provide guidance for the FFTF systems designers.

Since the initial FFTF concept was described, it has been assumed that the Fast Test Reactor (FTR) would be housed in a containment building, or possibly, a confinement building. In addition to providing the detailed nuclear safety requirements for the FTR containment system, these criteria are intended to provide guidance for deciding which specific systems may be housed in structures provided with a confinement system, and which systems may be housed in conventional industrial type structures.

A containment or confinement system is designed to minimize the escape of radionuclides from a nuclear facility. These systems are designed and constructed to perform with a high degree of reliability.

- A containment system is a system which depends upon a pressure-tight vesse1 to contain the vapor released from a reactor accident, thus preventing the spread of radionuclides to the environs.

- A confinement system depends upon ventilation control and treatment of exhaust ventilation air to remove airborne radionuclides other than the noble gases before the air is discharged through a stack. 


\section{SUMMARY}

In the FFTF the systems and materials which serve as sources of radionuclides are the FTR, discharged fuel, preirradiated fuel, irradiated materials test specimens, contaminated equipment, reactor cover gas, and process sodium. The fission product inventory, available energy, chemical reactions, and potential for fission product release accidents were considered in determining which FFTF systems should be housed in containment systems.

It is recommended that the following systems be housed in reactor containment buildings:

- FTR, including the primary coolant system and reactor cover gas system

- Reactor Refueling System

- Interim Fuel Decay Storage

- Closed Loop Primary Coolant Equipment Cel1s

- Short Term Irradiation Facility - Fuel

- Nuclear Proof Test Facility

It is further recommended that at least confinement systems be provided for the following:

- Short Term Irradiation Facility - Nonfuel

- Inert Gas Examination Cells

- Underwater Examination and Fuel Storage Basins

- Fuel Receiving and Assembly Areas

- Primary Coolant Sodium Processing and Storage and Loadout Ce11s

- Contaminated Equipment Maintenance Cells

\section{DISCUSSION}

\section{SOURCES OF RADIONUCLIDES}

In the FFTF, radioactive materials are produced, processed, or stored, in a number of systems. 
The FTR

The reactor core is the principal source of fissile material, fission products, and activation products in the facility. The reactor core contains the greatest concentration of radionuclides in the facility.

The primary coolant, sodium, is radioactive because of activation of the sodium, and will probably be contaminated with fuel, fission products, and activation products from structural materials.

$\underline{\text { Discharged Fue1 }}$

Irradiated fuel discharged from the FTR constitutes the greatest inventory of fission products and fissile materials outside the reactor core.

Preirradiated Test Fuel

Some test fuel pins may have been irradiated in another reactor. Preirradiated fuel pins could represent a significant inventory of fission products.

Irradiated Materials Test Specimens

Irradiated materials test specimens will be a significant source of activation products. Fission products will be present only as external contamination.

Contaminated Equipment

Process equipment removed for replacement or repair could be radioactively contaminated with fission products or activation products, or could itself be activated, if it had been used in the core.

Process Sodium

Sodium removed from the primary coolant system will contain ${ }^{22} \mathrm{Na}$ and ${ }^{24} \mathrm{Na}$ as well as possible fission product contamination. 


\section{Cover Gas}

The cover gas will contain activation products and gaseous fission products from vented or leaking fuel elements. Nuclear Proof Test Facility

Although the core of the nuclear proof test facility will be essentially free of fission products, occasional test elements will possibly have been irradiated in other reactors to give significant inventories of fission products in these elements. Also, a significant inventory of fission products could be generated in the driver core in the event of an accidental nuclear excursion. CONSIDERATIONS FOR CONTAINMENT REQUIREMENT

In determining whether containment or confinement should be recommended for a given system the following characteristics of the system were considered:

Fission Product Inventory

The gross quantity of fission products available for release in an accident was considered. Cooling time since the fuel was irradiated is also an important consideration because the heat generation rate decreases with time after irradiation, thus reducing the potential for thermal damage to the fuel. The estimated fission product decay energy of FTR fuel is given in Appendix A. Also, since the more volatile fission products tend to have shorter half Iives than the less volatile fission products, the radiological consequences of damaging fuel element jackets generally decrease as the cooling time increases. (1)

1. E. C. Watson. "Environmental Radioactive Contamination as a Factor in Nuclear Plant Siting,"HW-SA-2809. General Eizestrie company, Nareh 1963. 


\section{Available Energy}

A serious release of fission products can occur only when sufficient energy is available to disperse the fission products. Fission energy from the reactor core, energy generated by fission product decay, as well as the sensible heat of the coolant, fuel, and core structure, are taken into consideration when assessing the potential for a serious fission product release. Fission Product Release Accidents

Any accident which could result in fuel melting or jacket rupture would release fission products and possibly core material.

\section{Chemical Reactions}

Sodium fires or sodium-water reaction could not only lead to the dispersal of radionuclides, if the sodium is activated or contaminated, but would contribute significant amounts of energy to the containment or confinement system. APPLICATION OF CONTAINMENT CRITERIA

The FTR, in addition to being the principal source of fission products and activation products in the FFTF, is assumed in the design basis accident to generate a large quantity of excess energy which results in core meltdown and disassembly. In an accident of this type the primary coolant system and the reactor gas blanket system, as well as the core, would be involved. Therefore, the FTR, including the whole of the primary coolant system and the reactor gas blanket system, should be housed in a containment system. Reactor Refueling

The fuel handiing system will be used to discharge irradiated fuel elements from the reactor as well as to charge 
fuel elements. In performing manipulations within the reactor core, the fuel handling system will be in direct contact with a large inventory of fission products and activation products. Fuel changes performed shortly after reactor shutdown will involve handling fuel elements with high rates of energy generation from fission product decay. During refueling it is conceivable that an accident could occur approaching the severity of the design basis accident. Fires involving primary coolant sodium could occur, if the fuel handling system is designed for operation in an air atmosphere. The Reactor Refueling System should be located within the reactor containment system. Interim Fue 1 Decay Storage

The Interim Fuel Decay Storage will be used for storing discharged fuel elements during the initial cooling period immediately after discharge from the reactor. A relatively large fission product inventory will be present in the freshly discharged fuel elements along with a high fission product decay heat-generation rate. The potential for a serious release of fission products from a large number of fuel subassemblies is great enough to justify location of the sodium cooled fuel decay storage within a containment system. A basis for determining the cooling time in the sodium cooled fuel element decay storage pool before transfer out of the containment vesse1 is discussed in Appendix A.

Closed Loops Primary Coolant Equipment Ce11s

The primary coolant loops of the Closed Loops will contain activated sodium and possibly fission product contamination from test fuel element failure. 
Since the closed 10op primary coolant passes through the reactor core, the cells housing closed loop primary coolant equipment should be within the reactor containment system. Short Term Irradiation Facility

The Short Term Irradiation Facility Fuel should be located within the reactor containment system as irradiated test specimens could contain a significant fission product inventory and conceivably require continuous cooling.

The out-of-reactor terminal of the Short Term Irradiation Facility Nonfuel would not need to be located within the reactor containment system as no fissile material would be present to generate fission products. If samples are transported through the containment shell in a tube, the tube must be equipped with automatic containment valves. Inert Gas Examination Cel1s

In inert gas examination cells where only a limited number of irradiated fuel elements may be present, the fission product decay energy could be great enough to melt fuel rods, if the gas cooling system for the fuel element should fail. Any pressure increase in the cell resulting from fission product decay energy should be easily relieved through a confinement system exhaust. A confinement system should be provided for inert gas examination cells.

Underwater Examination and Fuel Storage Basins

The water in examination and fuel storage basins should adequately cool the irradiated fuel elements being examined, stored, or loaded for shipment. A qualitative review of a criticality accident in the fuel storage basin is given in Appendix B. Although the probability of fission product release by fuel element melting occurring in a water-filled basin is low, the release of gaseous fission products from damaged or vented fuel elements is quite probable. 
Confinement should be provided for these facilities because the exhaust ventilation air from these cells should be filtered to remove any entrained fission products or halogens. Fuel Receiving and Assembly Areas

Unirradiated driver and test fuel should offer little hazard, since there would be virtually no fission product inventory or fission product decay energy. The fissile and fertile fuel isotopes will be the source of radionuclides in the unirradiated fuel. A significant hazard in receiving and handling unirradiated fuel is the possibility of an accidental criticality. This hazard will be minimized by design of the facilities to provide for critically safe spacing during storage and handing. The receiving, storage, and assembly areas for unirradiated fuel should be housed in confinement type structures provided with positive ventilation control to prevent the spread of fuel core material in the event of fuel rod damage.

If test fuel elements are received which have been previously irradiated in another reactor, they will have to be handled in the facilities provided for storage and examination of irradiated fuel.

Primary Coolant Sodium Purification and Storage Cells

The sodium in the primary coolant purification cells and the sodium drained from the primary coolant system will contain neutron activation products, ${ }^{22} \mathrm{Na}$ and ${ }^{24} \mathrm{Na}$, and possibly, fission product contamination from fuel element failures. However, release of these radionuclides would require a sodium fire or a sodium-water chemical reaction. Because water will be excluded from sodium purification and storage cells, a sodiumwater chemical reaction would be improbable. Inert gas or oxygen-depleted atmospheres in these cells would preclude the occurrence of a sodium fire. 
Confinement cells would provide adequate protection for the storage of activated and/or contaminated sodium drained from the primary coolant system, and for housing primary coolant system purification equipment. These cells should have either an inert gas atmosphere or an oxygen-depleted atmosphere. Any exhaust system from the confinement cells should be equipped with roughing filters for removal of sodium oxide followed by high efficiency particulate filters and halogen absorbers.

Filling drums with scrap liquid sodium or reacting the scrap sodium should be done in a confinement cell. Contaminated Equipment Maintenance Cells

Contaminated process equipment must be handled in specially designed facilities to prevent the spread of radioactive contamination. The inventory of radionuclides associated with contaminated equipment is relatively small compared to the inventory of fission products in irradiated fuel. Also, energy for release or dispersal of the radionuclides is not readily available. Cells designed for cleaning or repairing contaminated process equipment should be of the confinement type and provide adequate biological shielding and filtration of the exhaust ventilation.

Nuclear Proof Test Facility

The core of the Nuclear Proof Test Facility (NPTF) should accumulate a relatively insignificant inventory of fission products in normal, planned operation. However, if preirradiated fuel elements are tested in the NPTF, a significant inventory of fission products could be present, and the need for continuous cooling of the fuel element would compound the hazard. If the test program in the NPTF is to include tests with preirradiated fuel elements a containment system should be provided. For a test program concerned 
only with unirradiated fuel samples, the NPTF could possibly be housed in a reactor confinement system. In either case, the system should be capable of withstanding the NPTF design basis accident and should be independent of the FTR containment system.

\section{CONTAINMENT SYSTEM OPERATION}

It is planned that fuel movement will take place in the reactor refueling cell while the reactor is operating. These operations are necessary if there is to be a real hope of achieving a plant availability of $75 \%$. The FTR containment system will be designed to permit persomnel access during reactor operation to those locations in the containment building where radiation levels are low enough to permit safe entry.

Penetrations of the containment shell are necessary in addition to personnel access, ventilation, process streams, fuel transfer, electric power, process instrument signal transmission, etc. Electrical conductors will be installed in penetrations in a manner that will give a dependable seal. Personnel access will be through air locks fitted with double doors which are interlocked to prevent opening both doors simultaneously. Ventilation supply and exhaust 1 ines will be equipped with dual containment valves in series. If fuel subassemblies are to be transferred from, or into, the containment building while the reactor is operating, an air lock or other device providing equivalent protection against breaking containment will be provided. Process lines penetrating the containment shell will be provided with dual containment valves in series, if these 1 ines could serve as an escape path for the contained atmosphere after an accident. 
The nature of the nuclear fission process which continues to evolve heat after reactor shutdown, requires continuing cooling of the reactor core and removal of the heat from the containment system. A reactor containment system provided for the protection of the public must be designed to operate effectively without increasing the damage to the reactor facility to a greater extent than the damage caused by the accident. We propose that this philosophy of operation be met by providing two stages of automatic operation of the containment system--ventilation containment and total containment.

- Ventilation containment would be automatically actuated upon an indication that the concentration of radionuclides in the exhaust air stream from the containment system exceeds a preset limit. A ventilation containment trip would trip the reactor safety circuit and cause closure of the containment valves in the ventilation supply and exhaust lines.

- Total containment would be automatically initiated upon simultaneous or consecutive indication of an excessive concentration of radionuclides in the exhaust ventilation stream from the containment building, and an increase of the containment building pressure to a preset limit. A total containment trip would trip the reactor safety circuit and cause automatic closure of process line containment valves in addition to closure of the ventilation line containment valves.

Heat must be removed from the reactor core after an accident to prevent escalation of the damage by undissipated fission product decay heat. The secondary coolant system and the emergency cooling system provides the only significant heat sinks available to the primary coolant system. Continued circulation of the secondary coolant is necessary for arresting facility damage by molten fuel. Since accident 
amage to secondary coolant 1 ines could conceivably open a route so the atmosphere for contained radionuclides, a study will be initiated to determine the need for containment valves which could be closed manually in the event of secondary coolant line damage. If containment valves are provided in secondary coolant lines they should not be closed automatically by the containment trip circuit.

\section{DESIGN SAFETY CRITERIA}

\section{CONTA INMENT}

- The containment system will be designed to limit the release of radionuclides to the atmosphere in any accident, including the design basis accident, to quantities that will be within the limits of the AEC Site Criteria, 10 CFR 100.

- The maximum leakage rate permitting compliance with 10 CFR 100 at the design pressure, after instaliation of all process equipment, will be establisheci by engineering studies.

- The containment system will be designed in accordance with the seismic design criteria to be developed with the aid of a recognized seismic expert consultant.

- The design pressure and temperature for the containment vessel will be equal to the estimated pressure and temperature resulting from the design basis accident, including a concurrent sodium fire.

- The system will be capable of attenuating the shock energy from the design basis accident.

- The containment shell will be protected from penetration by missiles generated by facility equipment or reactor accidents.

- Al1 piping which penetrates the containment shell will be equipped with dual shutoff valves in series, if these pipes could serve as an escape path for the contained 
atmosphere after an accident. (A study will be initiated to determine the need for dual containment valves on the secondary coolant system sodium lines.)

- Air locks and transfer devices will have interlocks to preserve the containment system integrity at all times.

- An automatic, containment, trip system will be provided.

- Upon an indication of an excessive concentration of radionuclides in the exhaust ventilation air from the containment vessel, the reactor safety circuit will be tripped and the valves in the supply and exhaust ventilation lines will be closed automatically.

- Upon an indication of an increase in the containment vessel pressure in addition to a ventilation containment trip, the containment valves in all lines penetrating the containment shell will be closed automatically after a suitable time delay to allow the reactor power to decay. Valves in process lines vital to continued cooling of the reactor core will be provided with a manual override--operable after initiation of automatic containment valve closure.

- Equipment will be provided for the removal and trapping of airborne radionuclides from the contained air.

- The containment structure will be designed to accommodate leakage testing and surveillance testing as follows:

- Leakage rate tests (initial and periodic retest) at design pressure after all penetrations have been installed

- Demonstration of leak tightness of penetrations at any time throughout the lifetime of the reactor

- Periodic leak testing of the containment isolation valves 
- Devices will be provided to preserve the integrity of the containment system, if a negative pressure should develop.

- If a steel containment shell is used, it will be designed and constructed in accordance with ASME Code for Pressure Vessels, Section III. The steel selected will have an NDT that is $30^{\circ} \mathrm{F}$ below the expected minimum ambient temperature. If a concrete pressure vessel is used, it will be designed and constructed to comparable engineering standards.

- An emergency personnel air lock will be provided in addition to the main personnel air lock.

\section{CONFINEMENT}

- Confinement systems will be designed to limit the release of radionuclides in any accident to quantities that will be within the 1 imits of the AEC Site Criteria, 10 CFR 100.

- The quantity of radionuclides routinely released from the FFTF confinement systems will be within the limits of AECM 0524 (10 CFR 20).

- Exhaust vapor or ventilation air from confinement systems will be passed through a filtration facility, prior to discharge to atmosphere through a stack. The filtration facility will contain particulate and halogen removal devices exhibiting no less than $99.0 \%$ particulate removal efficiency (0.3 micron size or larger) and $95.0 \%$ halogen removal efficiency (based on ${ }^{131}$ I) for the installed devices.

- Exhaust air from confinement cells will be passed through high efficiency particulate filters as it leaves the cell. (99.0\% particulate removal efficiency for $0.3 \mathrm{micron}$ or larger).

- Design of the air filtration facility will provide for periodic testing of the filtration efficiency. 
BNWL- 607

APPENDIX A

ESTIMATED FISSION PRODUCT DECAY HEAT 


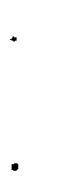




\section{APPENDIX A}

\section{ESTIMATED FISSION PRODUCT DECAY HEAT}

F. Swanberg

The estimated fission product decay heat generated in the 937 liter FTR core was compared with the PRTR batch core to provide a basis for out-of-core cooling requirements for irradiated fuels. In both cases the total energy produced was taken as the sum of the shutdown transient, the beta power after shutdown, and the gamma power after shutdown.

Figure 1 shows the decay power in terms of percent of equilibrium power as a function of time after shutdown.

Figure 2 compares the decay power per unit mass of fuel in kilowatts per kilogram in the FTR and the PRTR batch core.

In Figure 1 the photoneutron contribution in the heavy water system is readily apparent immediately after shutdown, diminishing rapidly during the next $10 \mathrm{sec}$. Estimates of total decay power and specific power of fuel elements during the first $8 \mathrm{hr}$ after shutdown can be made from Figure 1.

Figure 2 permits one to estimate the relative cooling requirements for fuel elements removed from the core at some time after shutdown with reference to the PRTR experience.

In general, considering equal masses, the FTR fuel can be expected to be an order of magnitude "hotter" than PRTR fuel at times of interest; therefore, out-of-reactor cooling requirements will be more critical than in the PRTR case.

The data for the PRTR batch core were taken from HW-61236, "Plutonium Recycle Test Reactor Final Safeguards Analysis and Supplements." The assumed mass of the PRTR fuel was $1845 \mathrm{~kg}$ based on 55 fuel elements, and equilibrium power was taken as $45 \mathrm{MW}$. The FTR data were based on a computer 
program supplement FAS-LIB ${ }^{(1)}$ developed by $W . L$. Bunch and D. R. Marr which provides a library for fast reactor studies using RIBD. (2) The fuel mass was calculated as $2554 \mathrm{~kg}$ and equilibrium power was taken as $400 \mathrm{MW}$. During the planning stage for PRTR is was expected that $3 \mathrm{hr}$ after reactor shutdown, a fuel element could be discharged and transferred out of the containment vessel to the water-filled storage basin. $(3,4)$ In Figure 2 the specific power of a PRTR fuel element at $3 \mathrm{hr}$ after shutdown is shown to be $0.145 \mathrm{~kW}$ per $\mathrm{kg}$. This figure also shows that the specific power of an FTR fuel element would take about 200 days to decay to the same level. Using this comparison as a basis, it is suggested that FTR fuel elements be cooled for 100 to 200 days in the sodium cooled fuel element decay pool before they are transferred out of the containment system to the water-filled storage basin.

1. W. L. Bunch and D. R. Marr. Fast Reactor Library for Use With RIBD, BNWL-CC-868. Pacific Northwest Laboratory, Richland, Washington. October 17, 1966.

2. J. L. Rash. Use of Computer Code RIBD for Fission Product

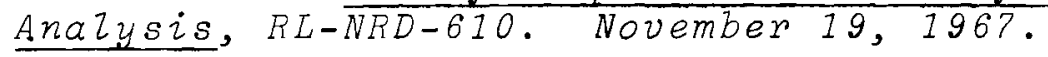

3. J. K. Anderson and W. K. Winegardner. Plutonium Recycle Critical Facility, Final Safeguards Analysis, $H W-69168$, p. 14. General Electric Company, Richland, Washington. February 1962 .

4. N. G. Wittenbrock, P. C. Walkup, and J. K. Anderson. Plutonium Recycle Test Reactor, Final Safeguards Analysis, HW-61236, pP. 169-170 and 245. General Electric Company. Richland, Washington. october 1959. 


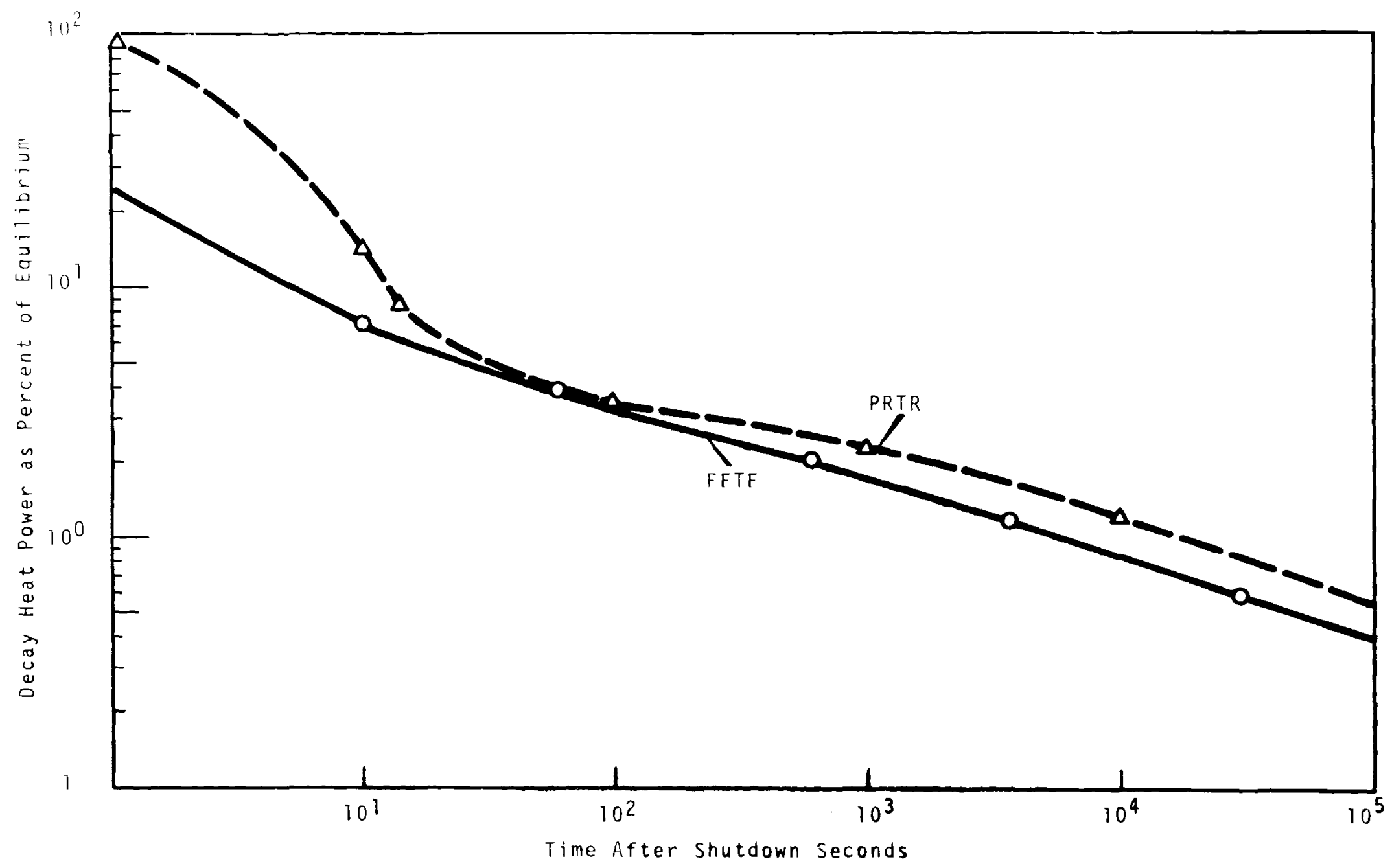




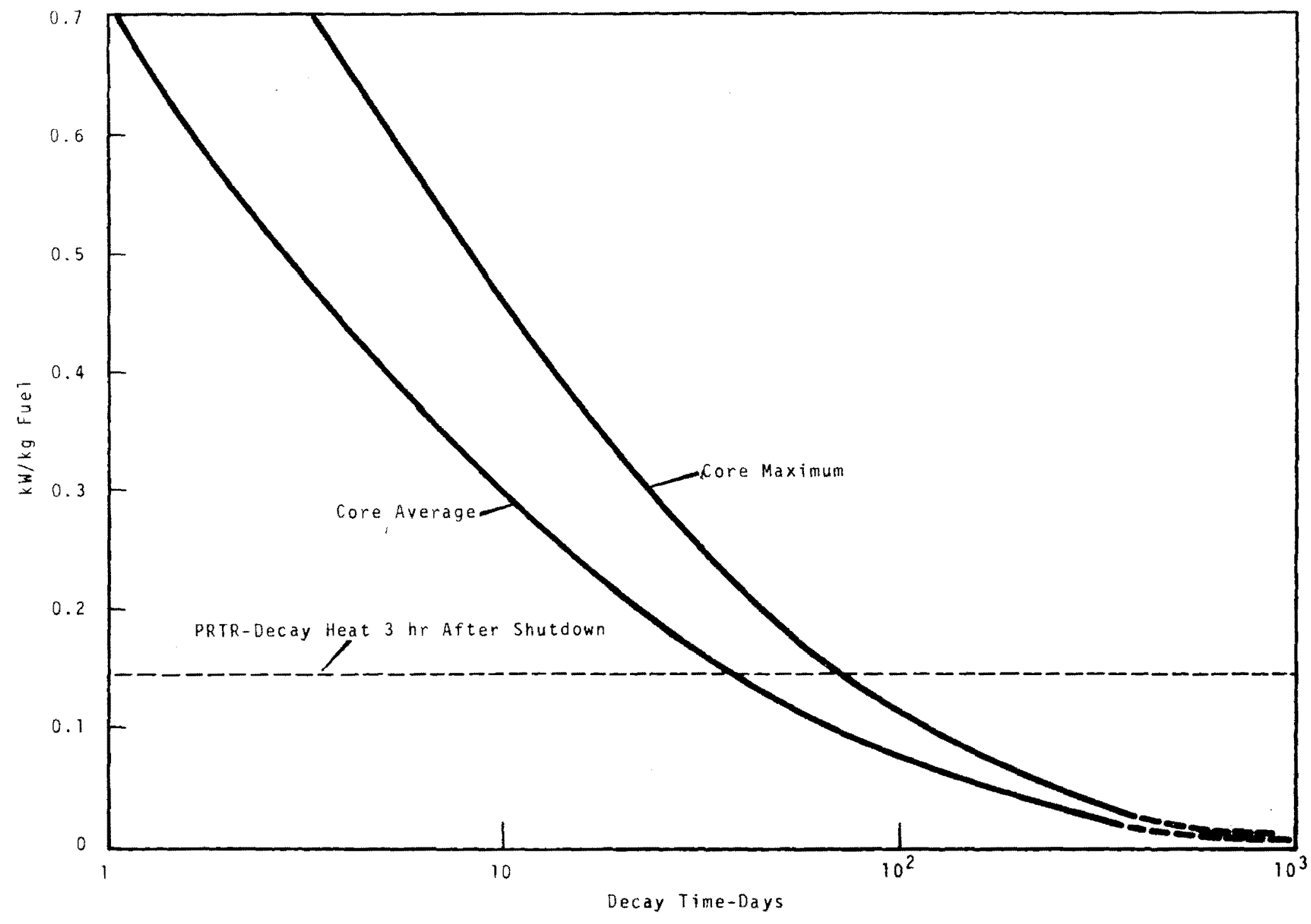


BNWL -607

APPENDIX B

FFTF FUEL STORAGE BASIN CRITICALITY ACCIDENTS 


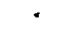

.

. 


\section{APPENDIX B \\ FFTF FUEL STORAGE BASIN CRITICALITY ACCIDENTS \\ V. W. Gustafson}

INTRODUCTION

It has been proposed that storage and loadout of FTR spent fuel be carried out in a water-filled basin. While design of the basin and handling and storage procedures are effective in preventing criticality accidents, it is of interest to consider the possibility and the consequences of such an accident.

\section{FUEL DESIGN AND CRITICALITY CONFIGURATIONS}

A proposed fuel subassembly design contains 217 pins of 0.18 in. diam arranged in a 4 in. hexagonal-shaped subassembly. A single subassembly of this design is subcritical in water. However, an estimated 110 pins arranged at an optimum spacing represents a single critical mass. Thus, one subassembly essentially comprises two minimum critical masses.

Three to five complete fuel subassemblies in water at optimum spacing constitute a critical configuration. In a close-packed arrangement, about seven subassemblies form a critical configuration. Assuming the subassemblies were voided of water, but water reflected, an estimated eight to eleven subassemblies are required for a critical arrangement at the optimum spacing. As expected, the rather large number of voided subassemblies (eight to eleven) compared to three to five water filled subassemblies for criticality, indicates the large reactivity worth of the water within the subassemblies. Thus, a rather large void coefficient exists. ACCIDENT ANALYSIS

Considerable time could be spent in analyzing the possible modes of reactivity accidents and the amounts of reactivity 
involved. It is more expedient at this stage to merely suggest the possibilities and estimate the consequences. Thus, for the current analysis, we will discuss two types of reactivity accidents-fast and slow addition. The latter are intended to mean sub-prompt-critical incidents.

SLOW REACTIVITY ADDITION ACCIDENTS

Accidents involving several subassemblies and those involving only a single subassembly are discussed separately. In an incident involving a single subassembly, it is hypothesized that the fuel pins are expanded or loosely arranged within the basin, since the complete assembly is subcritical because the pins are restrained by the hexagonal-shaped can to give a close packed arrangement.

Accidents Involving Several Subassemblies (three to five)

The type of accident envisioned would involve three to five subassemblies arranged in a near critical configuration, while an additional subassembly (or enough fuel pins to cause the array to become critical) is added at a slow rate, such as during a fuel movement operation in the basin. Assuming a slow ramp addition of reactivity, water within the subassemblies would heat up, and natural convection flow through the subassemblies would keep the fuel cooled. The rather large temperature (void) coefficient would slow the fission rate so that boiling would not occur for some time. A realistic temperature coeffieient of $0.1 \mathrm{mk} /{ }^{\circ} \mathrm{F}$ would require an excess reactivity addition of greater than $10 \mathrm{mk}$ before boiling would occur. Eventually, two-phase flow would restrict bulk flow and a gradual voiding of the subassembly would commence. Since the voiding coefficient is so significant, it would require that five to six subassemblies be added before the excess reactivity would be sufficient to completely void every 
subassembly of coolant. This type of situation appears unrealistic. The reactivity effect of adding one subassembly to a critical configuration might realistically void about $20 \%$ of the subassemblies before the steady state end condition would be reached. This would not be expected to cause any fuel damage, since the steam generated within the assemblies would keep the fuel cooled.

Accidents Involving a Single Subassembly (Pins)

The pins from a single subassembly arranged or expanded to a supercritical array would heat the water in the near vicinity of the rods. This could produce either positive or negative reactivity feedback, depending upon whether the fuel is arranged in an over or under moderated configuration.

In any event, the negative reactivity feedback from either heating or eventual boiling of the water would be of lesser magnitude than in the case with whole subassemblies. This is due in part to the larger volume of water to heat within the array as well as the better flow of heat to the surrounding pool of water. In addition, the negative temperature or voiding coefficient is smaller because of the greater fraction of moderator present in the array.

Thus, with boiling essentially assured for a continued slow reactivity insertion, it is possible that a sizable void would give some negative reactivity feedback, but it is probable that fuel pins would fail because of burnout, releasing fission products to the water.

Assuming that the rods were unconstrained, the boiling might cause an expansion of the configuration. If the expansion were to a more critical configuration, it is possible to initiate a fast reactivity addition accident as 
discussed later. A fission product release to the water would permit escape to the atmosphere of the noble gases; however, the remaining fission products would be, for the most part, retained by the water. The severity of any incident is probably dependent upon operator actions to stop the fission reaction, since there are no control elements to limit the criticality. Radiation alarms would detect criticality incidents or, since it is expected that incidents would occur during fuel handling, the operator should detect the incident and attempt to arrest the action. Boiling of water and/or Cerenkov glow would be indications that an incident was taking place.

\section{FAST REACTIVITY ADDITION ACCIDENTS}

Incidents involving subassemblies are discussed separately from those involving single pins.

Accidents Involving Several Subassemblies (three to five)

A fast reactivity addition accident is envisioned, if one were to have a near critical array and suddenly add another subassembly. A small amount of total reactivity change ( $1 \$$ or less) would produce consequences similar to those of a slow reactivity addition case already discussed. However, if the change is large and of short duration, the following would probably happen, 1 isted in the order of increasing severity.

- Water chugging in the subassembly, eventually reaching an equilibrium voiding condition It is reasonable that excess reactivity of the order of $1-2 \$$ could be added without damage to the fuel and that chugging would be minimal. Above $2 \$$ excess reactivity, chugging would occur and some fuel damage could be anticipated since the transient would be quite rapid with insufficient cooling for the fuel. Eventual chugging or voiding would limit the magnitude of the transient. 
- A large burst of steam in the subassembly that would propel it from the array by jet action at the bottom of the shroud The current design, as shown in BNWL-CC-400, shows the subassembly open at the bottom end and closed at the top end. Coolant exit channels at the top are located on the sides. Either subassembly movement or the voiding would terminate the transient. Fuel damage would occur.

- A rapid steam formation rate that would cause rupture of the subassembly can Fuel damage would be extensive. Sudden expansion would terminate the incident. This incident would require a very sudden insertion of reactivity with a total addition of at least 4 or $5 \$$. Accidents Involving a Single Subassembly (Pins)

Probably the classic example of a fast reactivity addition incident with fuel pins would be the expansion of a single subassembly containing approximately two minimum critical masses. Several dollars of reactivity could be added by the expansion, and it is probable that the array would continue to expand until the array became subcritical. In the period while the array was critical, however, it would be expected that boiling and fuel damage would result.

SUMMARY

The accidents reviewed show that criticality accidents in the FFTF water-filled storage basin could result in fuel damage. However, gross melting of the fuel in a criticality accident does not seem to be probable in any of the accidents considered. This is due to the large amount of water available for cooling the fuel, and the tendency in every case for either voiding or disassembly of the critical array to terminate a transient. Fission product release to the 
confinement space above the basin would be limited to the noble gases and a small fraction of the halogens. The confinement filter system would in turn reduce the halogen concentration to the point where no hazard to the public would exist.

FURTHER WORK

Analyses of the neutronic behavior of FFTF fuel in a watermoderated environment is not easily correlated with experimental thermal reactor transient results reported to date. It seems most likely that the behavior of a critical array of FFTF subassemblies in water should fall somewhere between the SPERT I oxide rod tests and the tests with plate type fue 1 conducted in Borax I before the destruction test.

Continued work on this subject would be directed to a study of the self-limiting characteristics of the fuel-water arrangement, including the effects of the Doppler coefficient and a refinement of the estimate of the void coefficient. Quantitative estimates of the transient results could be obtained by fitting the transient characteristics of the burst to a program capable of performing transient heat transfer calculations. Probably the most difficult item to predict is the magnitude of an excess reactivity addition. As this review indicates, there exists a potential for a rather large range of reactivity addition and rates of addition, thus giving a wide range of severity of the consequences. 


\section{DISTRIBUTION}

Number of Copies

U. S. Atomic Energy Commission, Washington

M. Shaw, Director, RDT

Asst Dir for Nuclear Safety

Analysis $\&$ Evaluation Br, RDT:NS

Environmenta1 \& Sanitary Engrg $\mathrm{Br}, \mathrm{RDT}: \mathrm{NS}$

Research \& Development Br, RDT:NS

Asst Dir for Plant Engrg, RDT

Applications $\mathcal{G}$ Facilities $\mathrm{Br}$, RDT:PE

Components $\mathrm{Br}$, RDT:PE

Instrumentation \& Control $\mathrm{Br}$, RDT:PE

Systems Engineering $\mathrm{Br}$, RDT:PE

Asst Dir for Program Analysis, RDT

Asst Dir for Project Mgmt, RDT

Liquid Metals Projects Br, RDT:PM

FFTF Project Manager, RDT:PM (3)

Asst Dir for Reactor Engrg

Control Mechanisms Br, RDT:RE

Core Design $\mathrm{Br}$, RDT:RE

Fuel Fabrication $\mathrm{Br}$, RDT : RE

Fue 1 Handling $\mathrm{Br}$, RDT : RE

Reactor Vessels Br, RDT:RE

Asst I)ir for Reactor Tech

Chemistry \& Chemical Separations

$\mathrm{Br}, \mathrm{RDT}: \mathrm{RT}$ (2)

Fue $1 \mathrm{~s}$ \& Materials Br, RDT:RT

Reactor Physics Br, RDT:RT

Special Technology $\mathrm{Br}$, RDT:RT

ALC Chicago Patent Group

G. H. Lee, Chief

R. K. Sharp

AEC Idaho Operations Office

Vuclear Technology livision

C. W. Bills, birector

NLC Richland Operations Office

FFTF Project office (2)

Ingineering \& Construction Div (1)

J. I1. Krema 
Number

$\frac{\text { of Copies }}{1}$

AEC San Francisco Operations Office

Director, Reactor Division

$\because 4$

AEC Site Representatives - PNL

P. G. Holsted (2)

L. R. Lucas

A. D. Toth

4

AEC Site Representatives

Argonne National Laboratory

Atomics International

Atomic Power levelopment Assoc.

General Electric Co.

Argonne National Laboratory

R. A. Jaross

LMFBR Program office

2

Atomics International

L. F. Cilasgow

R. W. lickinson

Atomic Power Development Assoc.

B. V. D. Farris

Babcock \& Hilcox Co.

S. H. Esleech

T. P. Farrel1

Combustion Engineering

Dr. W. P. Stoker

Genera 1 Myamics Corp.

1). Coburn

General Electric Co.

Dr. karl cohes (3)

Bertram llolfe

Idaho Nuclear Corporation

I). R. deBoisblanc 
Number

of Copies

1

87
PNL Representative

N. A. Hill (ZPR III)

Stanford University

Dr. R. Sher

Battelle-Northwest

G. E. Akre

W. G. Albert

S. O. Arneson

E. R. Astley

J. M. Batch

R. A. Bennett

J. R. Boldt

C. L. Boyd

D. C. Boyd

C. L. Brown

W. L. Bunch

C. P. Cabe 11

A. C. Callen

J. R. Carrel1

W. E. Cawley

W. L. Chase

T. T. Clauds on

P. D. Cohn

D. L. Condotta

J . H. Cox

J. M. Davidson

V. A. Deliso

D. R. Doman

G. E. Driver

R. V. Dulin

J . F. Erben

L. M. Finch

R. C. Free

E. E. Garrett

S. M. Gill

V. W. Gustafson

R. A. Harvey

B. R. Hayward

J. W. Helm

R. J . Hennig

G. M. Hesson

P. L. Hofmann

J. E. Irvin 
B. M. Johnson

H. G. Johnson

R. N. Johnson

J. II. Kinginger

W. C. Kinse 1

D. D. Lanning

II. D. Lenkersdorfer

C. W. Lindenmeier

II. E. Little

W. W. Little

C. E. Love

D. E. Mahagan

W. B. McDonald

M. H. Meuser

R. A. Moen

C. A. Munro

D. M. Nero

M. G. Patrick

J. A. Perry

R. E. Peterson

W. E. Roake

J. D. Schaffer

F. H. Shade 1

D. W. Shannon (2)

D. L. Simpson (3)

C. R. F. Smith

R. J. Squires

G. H. Strong

C. D. Swanson

J. C. Tobin

K. G. Toyoda

M. Vogel

D. M. Walley

J. H. Westsik

L. A. Whinery

R. I. Widrig

T. M. Withers

N. G. Wittenbrock

M. R. Wood

F. W. Woodfield

FFTF File (2)

Technical Information Files (3)

Technical publications 